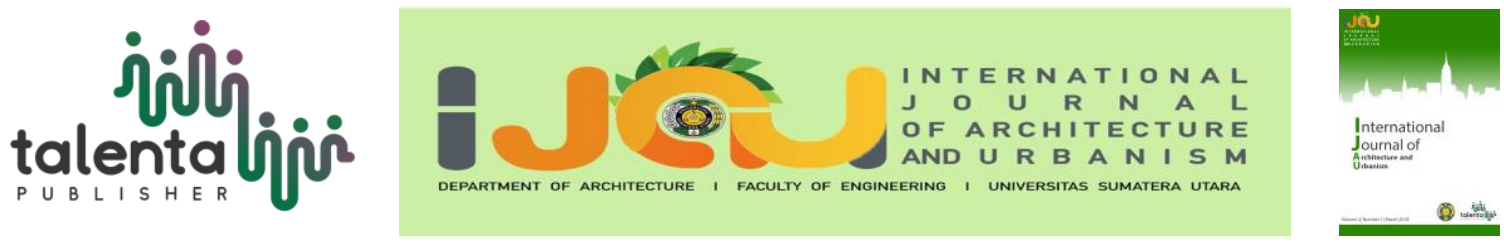

\title{
Medan Youth and Community Center
}

\author{
Samsul Bahri $^{1 *}$, Harun Arrasyid Sitorus ${ }^{1}$ \\ ${ }^{1}$ Department of Architecture, Universitas Sumatera Utara, Medan, Indonesia
}

\begin{abstract}
Medan City is one of the big cities in Indonesia that also can not be separated from the process of guidance and talent of the youth who often become issues that are closely linked with the nation's moral problems as a whole there is no guidance and talent for young people. At the regional level, the number of youths reaches $40 \%$ of the total population. It is the responsibility of the government to provide a means of talent development to boost the sporting achievements and youth work that will become leaders in the future. Based on the background of this problem required a facility that can support and develop the talent of the youths in the city of Medan.
\end{abstract}

Keyword: art, education, facility, sport

\section{Introduction}

The number of youth reaches $40 \%$ of the total city population of $2,121,053$ people based on RTRW (Region Spatial Plans) Medan City 2010-2030. It is the responsibility of the government and the community to provide recreation facilities and mainly aim to boost the achievements of sports and youth work. Youth as a generation who will be a leader in the future like in training to increase interest and talent in the field of positive to enhance leadership, high competitiveness, and mental sportsmanship.

By realizing the developmental needs of teenage interests and talents, this will prevent teenagers from unwholesome activities and tend to lead the cases of the moral decline of the nation as issues that are developing in today's society. Then it will also improve the standard of living of the adolescent itself as it gets new learning that can be used in the future. Based on some backgrounds and benefits that will be processed by the city of Medan, it is necessary to determine a strategic location to build a facility for the development of interest and talent of teenagers. The chosen place is in the area of East Medan because it is a strategic area when viewed from a location adjacent to the school and many educational centers visited by teenagers or residents of young age.

*Corresponding author at: Department of Architecture, Faculty of Engineering, Universitas Sumatera Utara,

Jalan Perpustakaan Gedung J07, Medan 20155, Indonesia

E-mail address: samsulbahrimail@gmail.com 


\section{Literature Review}

One of the largest cities in Indonesia which is the gateway to the western part of Indonesia and is the capital of North Sumatra province. The term for a transitional period between adolescence and adulthood, which is an economic and personal dependency. The community is a social group of some organisms that share the environment, generally having the same interests and habitats. The individuals in it have the purpose, belief, resources, preferences, needs, risks, hobbies and some other similar conditions [1]. Center is a place located in the center and is the center of some sub-points. While Medan Youth And Community Center is a teenage arena that serves to accommodate youth activities of Medan city to be able to develop talents both in the field of sports and the arts. This building also serves as a forum for socialization among youth in the context of a community center.

\section{Methodology}

The selection of space and program criteria from the Medan Youth And Community Center design is based on the grouping of several sites that have tested the feasibility of achievement, the feasibility of facilities around the site, the closest distance to the center of activities in Medan City, which are mostly schools and universities. Then in determining the program space and standards that are good for a teenage arena obtained from several studies comparing teenagers from various parts of the world.

\section{Result and Discussion}

The results of the design that has been achieved cannot be separated from various aspects of the background which are the necessary analyzes related to the location of the site located in East Medan. The existence of sites located adjacent to the center of youth activities in the form of schools and colleges to be more valuable. The easy access to the site from the central location of Medan City is a main point for a youth arena that will be accessible to many young people from all Medan city jurisdictions. Several other analyzes have also been conducted to obtain designs that minimize the architectural and social problems of the site [2]. Here is an outline of the analysis and concepts that are in the design process of Medan Youth And Community Center. The map besides describes the site in the right location (Figure 1). Because it is visible from a radius of $1 \mathrm{~km}$ from the site, there are many schools and colleges, making it easier for young people who learn to access the site. 


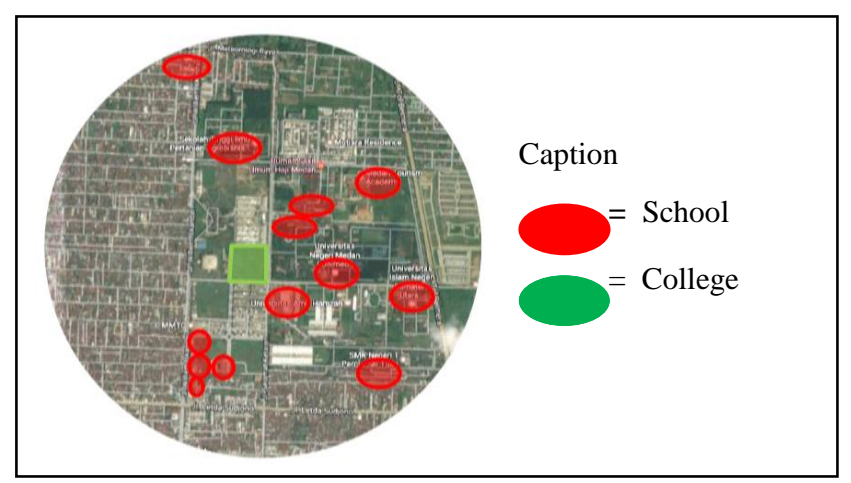

Figure 1. Site Analysis in a regional environment

Achievements to the project location can be accessed various modes in the city of Medan either through private or public transportation. The site location of Medan city center located at Lapangan Merdeka can be reached only \pm 5 minutes by vehicle, and about \pm 15 by foot (Figure 2). Circulation on the track at the site has one direction and has an alternative path, so there is ease to reach the location.

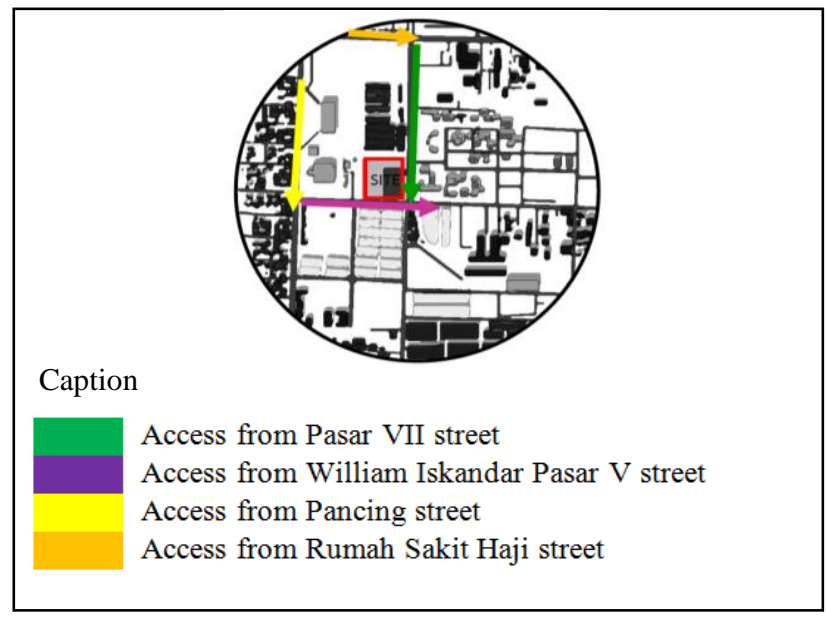

Figure 2. Site achievement analysis

The sun moves from east to west, where the site will be exposed to the most sunlight in the west because the afternoon sun is very stinging (Figure 3). Therefore, the site is attempted to minimize openings or to install vertical/horizontal blinds. Also, the selection of materials in the west will be considered to prevent the fading of color or damage to the physical material when all day is exposed to sunlight [4].

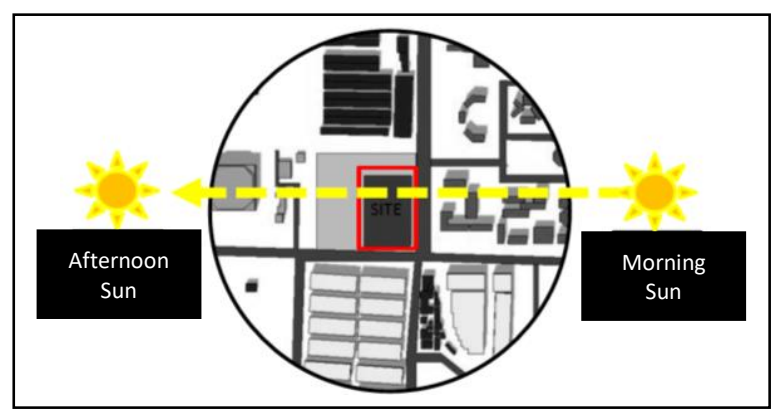

Figure 3. Sun orientation analysis 
Contemporary theme is synonymous with modern or up to date, but in design is often distinguished. This term is used to mark more advance, more responsive to social and technical problems, flexible and innovative, both in form and appearance and type of material. In this contemporary Youth and Community Center Medan design is intended to design a region that has many functions and can accommodate the needs of local youth in particular and the needs of surrounding communities in general (Figure 4).

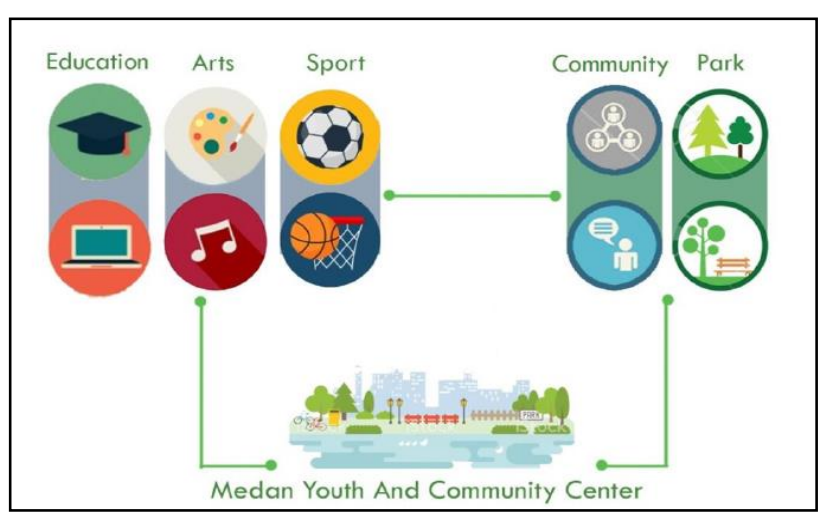

Figure 4. Basic design concepts

The hierarchy of the outer space of Medan Youth and Community Center building is divided into several sections (Figure 5). The entrance area on both of the road serves to facilitate access from all sides to the Medan Youth and Community Center area. At the corner which is the corner of the crossroads is a sports area and outdoor area for sports. There are also areas for communities in this area.

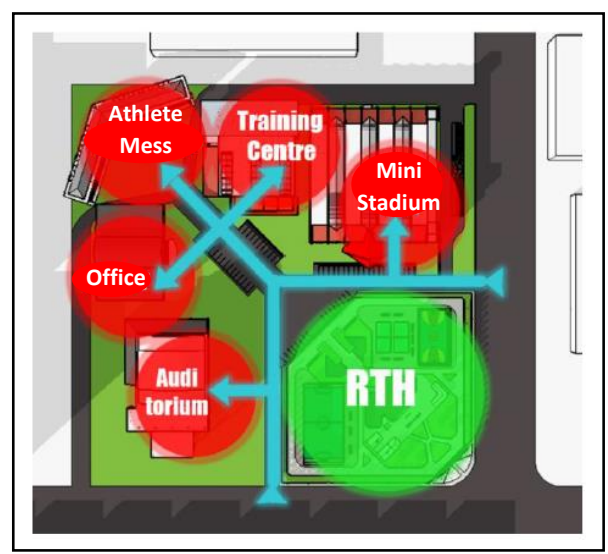

Figure 5. Outdoor concepts

The mass formation is formed because of the response to the surrounding natural phenomena. The mass of the building is divided into five masses that are connected to the main building. Potential sites located at a crossroads provide access to both directions. Road angle becomes more value at the existing site location (Figure 6). 


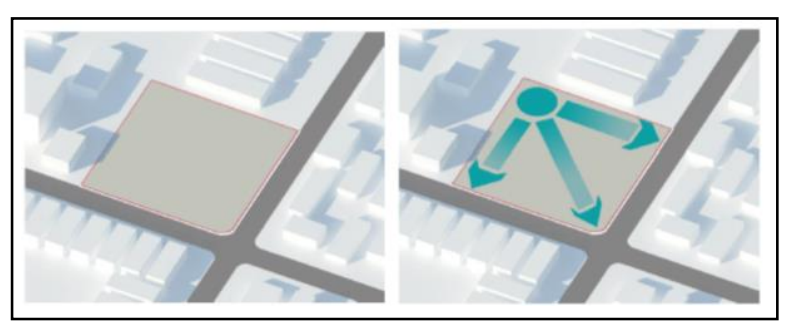

Figure 6. The concept of site direction

The site area on the corner of the road serves as a functional green area. There is an outdoor sports area and community venue to gather (Figure 7). Building masses are divided into five different functions including functional RTHs that support each other's functions (Figure 8).

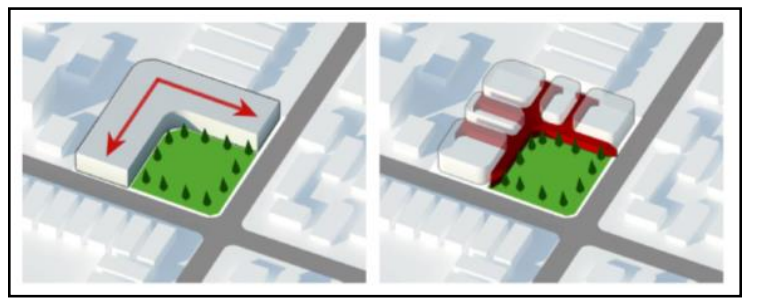

Figure 7. The Concept of massing

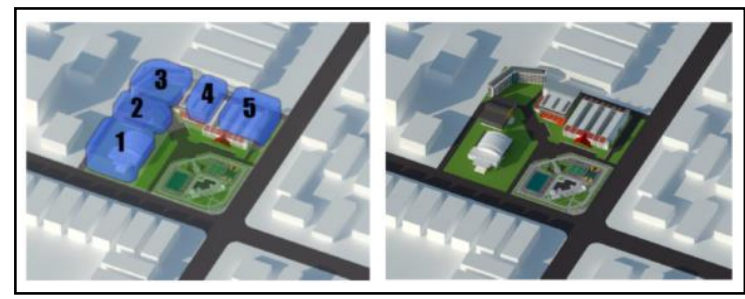

Figure 8: Function concept

The circulation applied in Medan Youth And Community Center area is the circulation contained on the sides between the outdoor facility area and indoor building. The purpose is so that view and access to each mass of buildings with different functions can be maximized (Figure 9).

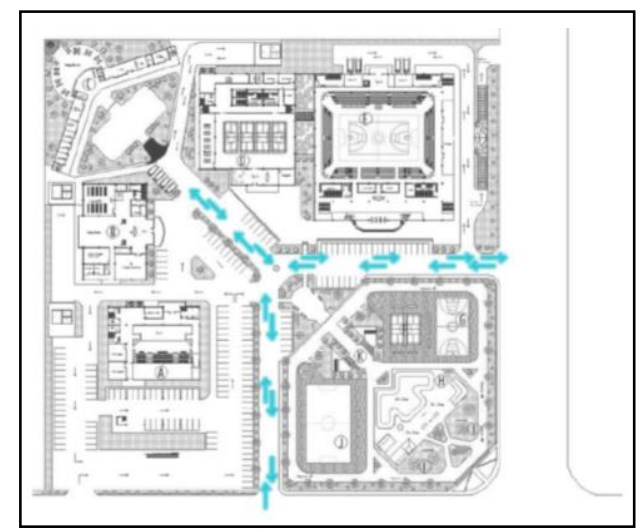

Figure 9. The concept of circulation 
The main line in the Medan Youth And Community Center is a road with a width of nine that can accommodate the flow of two-way vehicles (Figure10). Implementation of such a system is intended to prevent friends from congestion and congestion due to some building functions provide the capacity of many visitors such as auditoriums and mini-stadiums. This background is then the basis for the implementation of a two-way system in the region [3].

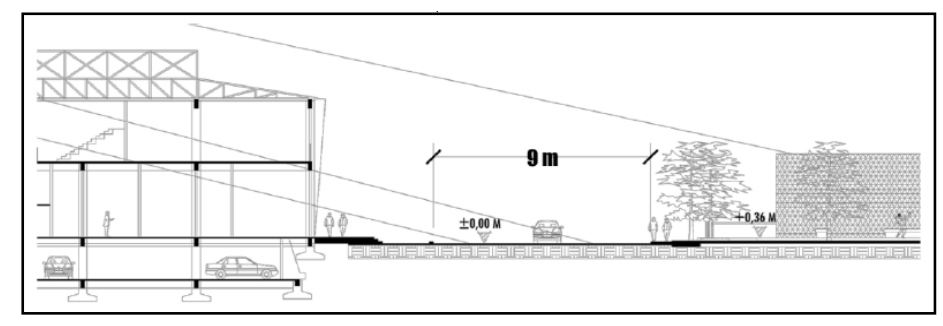

Figure 10. The circulation

Parking is at the site and is divided into several types. There is a major parking lot adjacent to the auditorium and is the main parking lot of the entire Medan Youth and Community Center area. Then there is off street parking in the area which is the parking which is on the road. This parking can be accessed by all visitors and specialize for visitors who come to the RTH which is an outdoor sports area to facilitate visitor access because it does not have to walk far to the parking area (Figure 11). The basement parking that is given a red color in the illustration above is the third or the last parking type in the area of Medan Youth And Community Center. It is located in the basement of the mini stadium and is additional parking for visitors to the area as well as the main parking lot for the mini stadium itself if there is a city or provincial scale game.

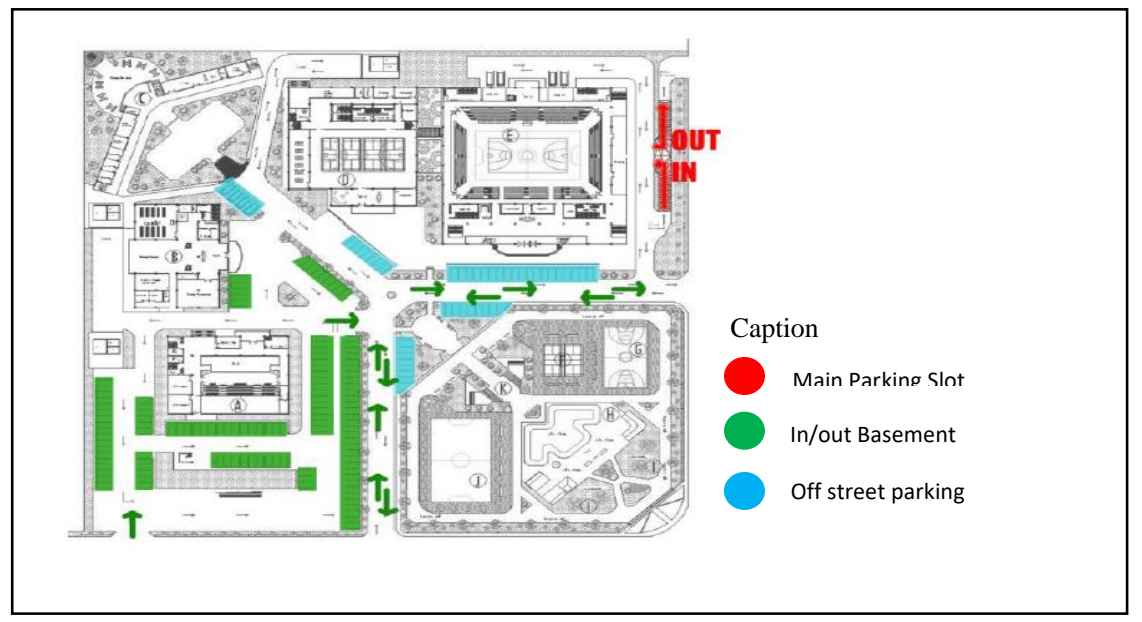

Figure 11. Parking concept

The outer green setting of the building is placed on the edge of the building as a shade. Some plants are also located on the area tangent as a buffer of the noise coming from the roads that exist around the site (Figure 12 and figure 13). 


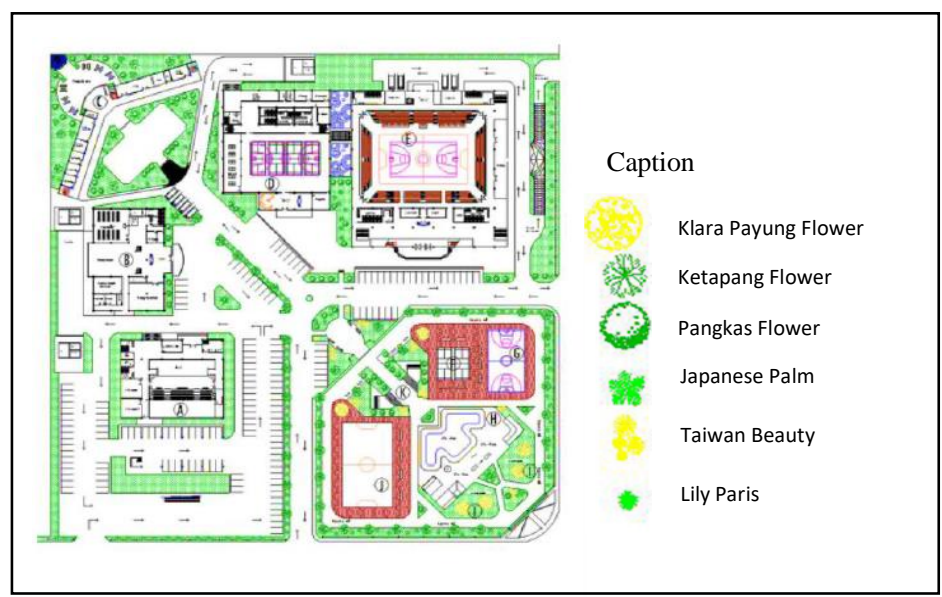

Figure 12. Landscape concept

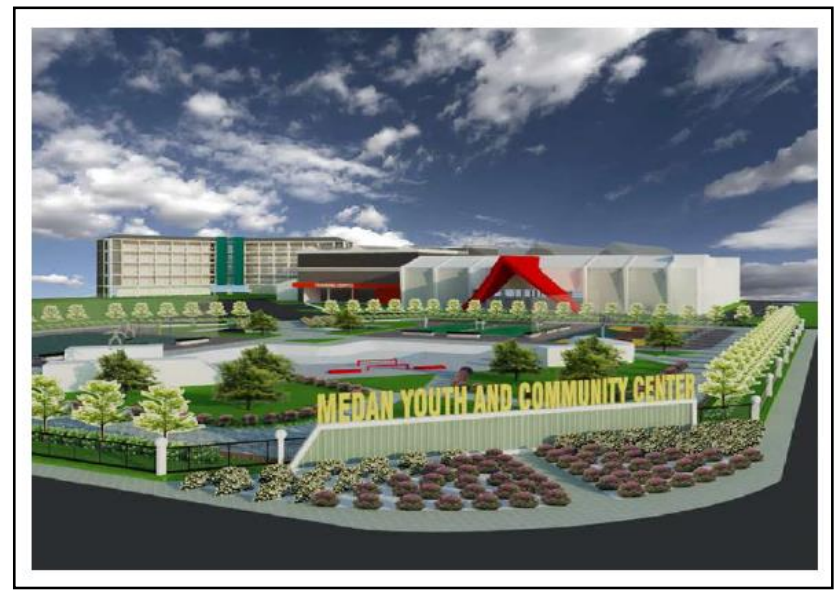

Figure 13. Perspective view of landscape

In the building (indoor) used artificial air system by using central conditioner for public spaces and split for a private room (Figure 14). The current source from PLN and the generator as backup power. If the current from the PLN goes off before the generator works, an uninterrupted power supply (UPS) uninterruptible power supply is used. Placement of the generator is outside the building, with a generator set (Figure 15).

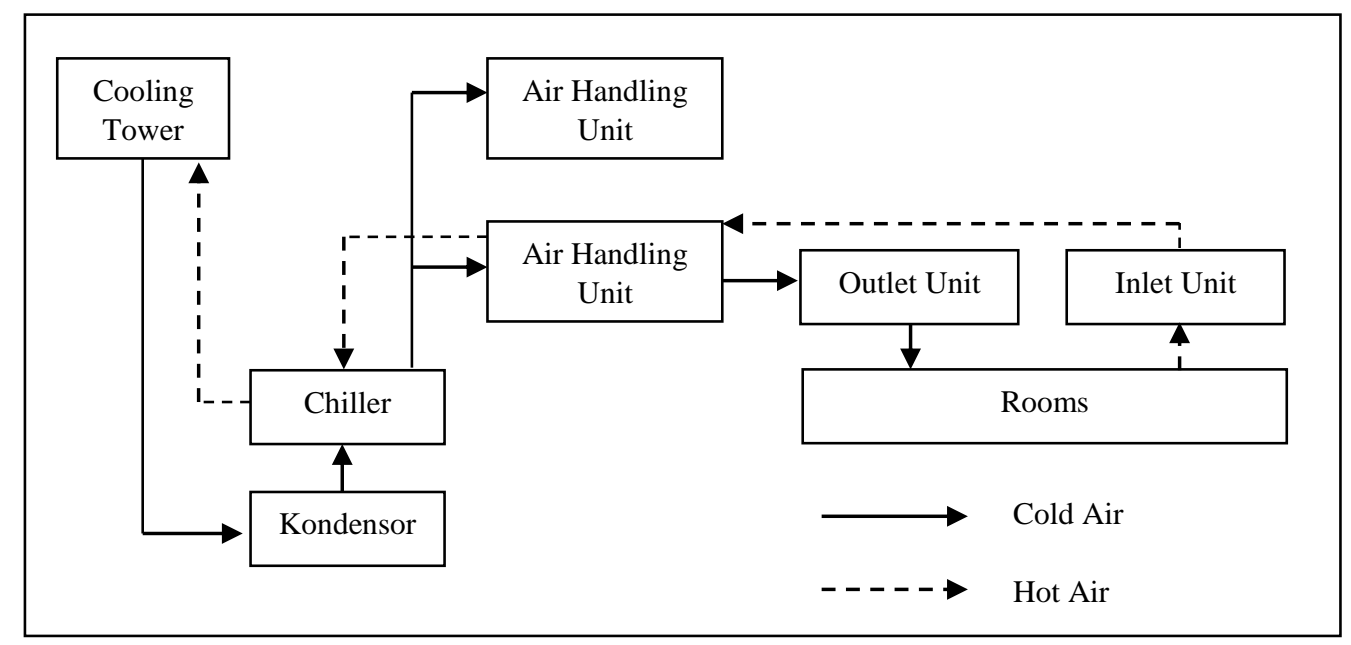

Figure 14. The Concept of air conditioning 


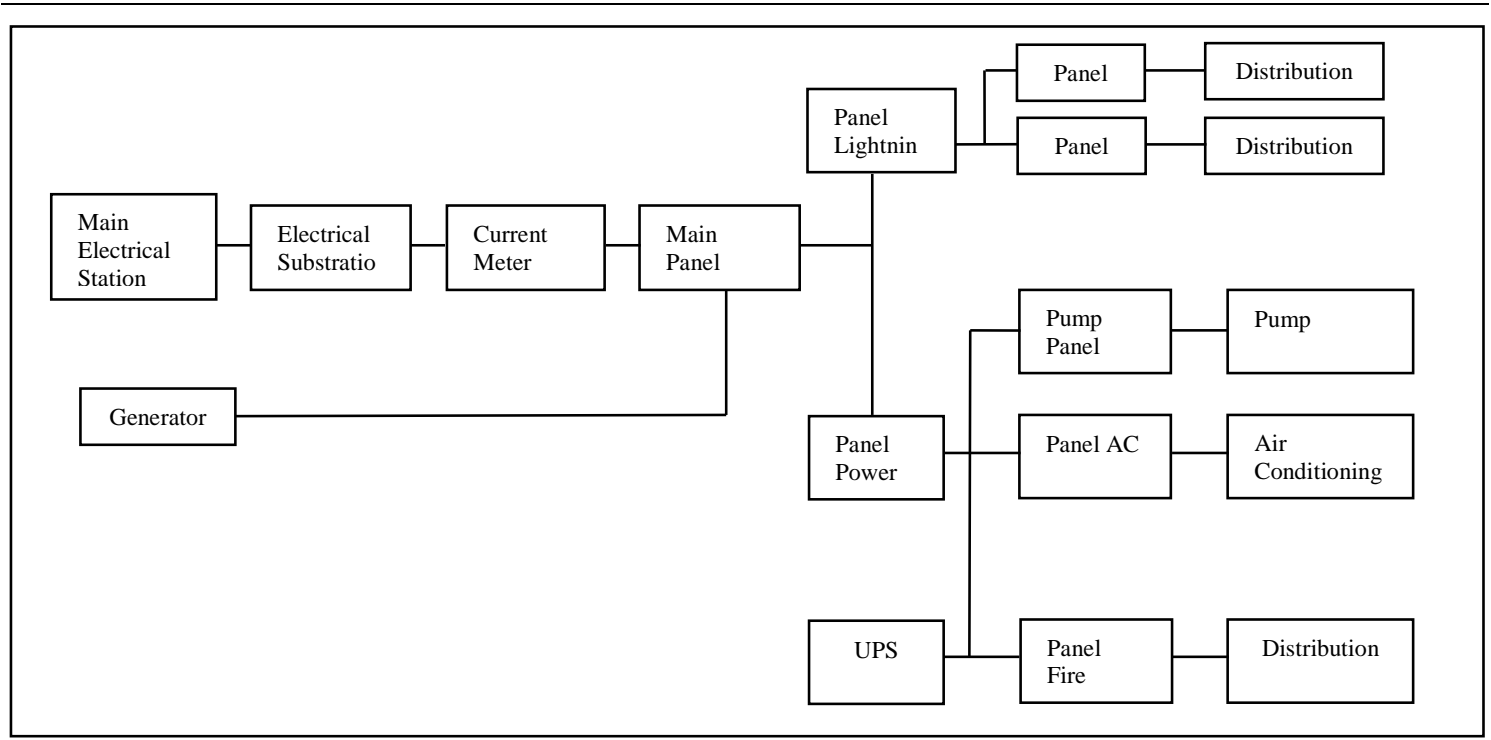

Figure 15. Electrical concept

\section{Conclusion}

Based on the background of the problems and needs of the teenagers in the city of Medan, it can be concluded several solutions from the existing problems. There are many shortcomings of the middle-class teenage arena in Medan City. The lack of facilities and the far-reaching of youth rinks from the center of youth activities are the two main problems of the youth rink currently in Medan, which is on Jalan Perintis Kemerdekaan. The teenage arena that should be in Medan City can be summarized from the following points.

First, Accommodates many teen activities ranging from sports education, arts, education, and also as a gathering place for youth or more often referred to as a community container to work and be creative. Second, Located close to the center of schools and universities that are mostly occupied by the population with teenage age. Third, Located not far from the city center. This building is very useful for accessibility to the teenagers. Fourth, Being in a place that is not too densely populated. As one of the facilities for the development of adolescents, then a youth rink should not be close to the hustle of industry or office for the educational process takes place comfortably and well. It is expected that Medan Youth and Community Center can improve the quality of nonformal education in Medan City as an effort to promote education and sportsmanship values of adolescents as leaders of the period with Medan City in particular and Indonesia in general.

\section{Acknowledgment}

This research is part of the requirement to obtain a bachelor's degree in Architecture Departement Universitas Sumatera Utara.

\section{REFERENCES}

[1] S. Bingler, L. Quinn and K. Sullivan. Schools as centers of community: A citizen's guide for planning and design. National Clearinghouse for Educational Facilities. 2003. 
[2] A. K. Dewi and I. A. Dharoko. Perancangan Yogyakarta Youth Center Yang Mencitrakan Karakteristik Remaja Dengan Pendekatan Arsitektur Kontemporer. Doctoral Dissertation, Universitas Gadjah Mada. 2016.

[3] E. Neufert. Data Arsitek Jilid 1 Edisi. 33. Jakarta: Erlangga. 1996.

[4] E. Neufert. Data Arsitek Jilid II. Jakarta: Erlangga. 2002. 